\title{
Corpo, desejo e trabalho na juventude: o cras e a análise institucional nos limites de uma governabilidade democrática
}

\author{
Renato Izidoro da Silva* \\ Gerson André Albuquerque Ferreira** \\ Tiago Marinho Dias*** \\ Francisco José Fernandes da Silva****
}

\section{Resumo}

O presente texto disserta sobre questões teórico-metodológicas e político-sociais levantadas durante um trabalho de extensão universitária cujo objetivo foi realizar (2011) uma Análise Institucional junto a um grupo de jovens atendidos por um dos Centros de Referência da Assistência Social (CRAS) existentes na cidade de Parintins-AM. Dentre alguns problemas enfrentados pelo presente trabalho, vale destacar os limites que a própria cultura institucional brasileira impõe ao campo educacional; tradicionalmente pautada na relação vertical, unilateral e hierárquica refletida na seguinte escala de poder: instituição, educadores e educandos. A mencionada relação vertical desempenha papel crucial na anulação, ocultamento e exclusão das constituições subjetivas, tanto coletivas quanto individuais, presentes e operantes no saber-fazer educativo institucional, levando objetivos democráticos a se contradizerem com as práticas inconscientemente autoritárias materializada no controle dos corpos ao nível dos pensamentos e dos gestos. Diante disso, a Análise Institucional de base psicanalítica opera no sentido de destituir a verticalidade da governabilidade no sentido de provocar a descentralização do poder e de seus mecanismos de produção.

Palavras-chave: Inconsciente. Consciente. Desejo. Trabalho. Corpo.

\footnotetext{
* Doutor e mestre em Educação pelo PPGE/UFBA. E-mail: izidoro.renato@gmail.com

** Doutorando em Sociedade e Cultura na Amazônia, Universidade Federal do Amazonas (UFAM). E-mail: sociologicus.ferreira@gmail.com

*** Graduando do curso de Educação Física: Licenciatura da Universidade Federal do Amazonas (UFAM). E-mail: simpison@hotmail.com

*** Graduando do curso de Educação Física: Licenciatura da Universidade Federal do Amazonas (UFAM). E-mail: fernando.mar2009@hotmail.com
} 


\section{Body, and desire in youth work: the cras and institutional analysis within the limits of a democratic governance}

\author{
Cuerpo, deseo y trabajo en la \\ juventud: el cras y el análisis \\ institucional en los límites de una \\ gobernabilidad democrática
}

\section{Abstract}

This text lectures about theoretical, methodological, social and political questions raised during an extension work that aimed to realize (2011) an Institutional Analysis with a group of teenagers attended by one of the Reference Centres for Social Work (CRAS) of the Parintins city (AM). Among some problems faced by this work, we point the limits the Brazilian institutional culture imposes to itself, traditionally guided by a vertical relationship, unilateral and hierarchical reflected in the following power scale: institution, educators and students. This vertical relationship plays the crucial role of in annulation, concealment and exclusion of the subjective constitutions, as well collective and individual, existing and operating in the educative know how, leading the democrat objectives to contradict unconsciously authoritarian practices on body control to the gesture and thoughts' level. So, the Institutional Analysis of psychoanalytical base acts in a way to destitute de verticality of the governance to provoke the decentralization of the power and its mechanisms of production.

Keywords: Unconscious. Conscious. Desire. Work. Body.

\section{Resumen}

Este trabajo trata sobre cuestiones teórico-metodológicas y político-sociales que surgieron durante un trabajo de extensión universitaria, cuyo objetivo era llevar a cabo (2011) un Análisis Institucional junto a un grupo de jóvenes asistidos por uno de los Centros de Referencia de Asistencia Social (CRAS) en la ciudad de Parintins-AM. Entre algunos de los problemas que se ha enfrentado este trabajo, vale la pena señalar los límites que la propia cultura institucional brasileña impone al ámbito educativo; tradicionalmente basada en la relación vertical, unilateral y jerárquica reflejada en la siguiente escala de poder: institución, educadores y educandos. La relación vertical mencionada desempeña papel crucial en la anulación, ocultamiento y exclusión de las constituciones subjetivas, tanto colectivas como individuales, presentes y activas en los conocimientos de la educación institucional, lo que lleva objetivos democráticos a que se contradigan con prácticas autoritarias inconscientemente materializadas en el control de los cuerpos en nivel de pensamientos y gestos. Por lo tanto, la base psicoanalítica del Análisis Institucional opera con el objetivo de derrocar la verticalidad de la gobernabilidad en el sentido de causar la descentralización del poder y de sus mecanismos de producción.

Palabras clave: Inconsciente. Consciente. Deseo. Trabajo. Cuerpo. 
Introdução às orientações do Sistema Único de Assistência Social (SUAS) para os Centros de Atendimento da Assistência Social (CRAS)

Com base em reflexões teóricas articuladas a dados empíricos, o presente texto estabelece uma relação dialética entre os modos tradicionais de dinâmicas de grupos e os processos propostos pela Análise Institucional (Al) psicanalítica no contexto de um CRAS durante um período de seis meses do ano de 2011. Fizemos uso de conceitos e dispositivos clínicos da psicanálise que visam à construção de consciência do sujeito em relação ao seu posicionamento no campo social do desejo, do poder, do ideal, do corpo e da lei. Compreende a linguagem e sua pragmática discursiva como indissociável de seus espaços e de seus sujeitos de produção articulados a ideais historicamente precedentes e geograficamente externos a eles. Problematiza os caminhos e as finalidades dos sujeitos, tendo como pano de fundo a dimensão do trabaIho psíquico enquanto processo social de construção das condições subjetivas e objetivas de realização do desejo na forma de realização de demandas em termos de articulações e desarticulações entre sujeito e o mundo do trabalho em termos sociais.

Inicialmente descrevemos as orientações Teórico-Metodológicas dos CRAS, conforme corpo legislativo e demais referenciais bibliográficos acerca da Política Nacional de Assistência Social (PNAS) orientada pelo Conselho Nacional de Assistência Social (CNAS). Pontuamos algumas características e padrões de fracasso e sucesso comportamentais das ações que buscam implementar o referencial Teórico-Metodológico ao nível do SUAS, mais especificamente os CRAS na condição de realidade empírica das políticas e diretrizes referentes à seguridade social brasileira. Apresentamos aspectos centrais do referencial Teórico-Metodológico da Análise Institucional de fundamento psicanalítico e de que maneira pode contribuir com princípios, fins e meios propostos pelo SUAS. A divisão da descrição dos procedimentos nessas duas partes tem como objetivo apresentar algumas das principais dificuldades na implementação do SUAS por meio dos CRAS e expor como a Al pode contribuir com a concretização da contemporânea Assistência Social brasileira, que busca, apoiada em técnicas, tecnologias e recursos humanos, superar as visões verticais e autoritárias das referências e práticas assistencialistas e patrimonialistas.

Como ponto de partida da compreensão Teórico-Metodológica dos CRAS, é preciso conhecer alguns dos principais aspectos dessa instância empírica da seguridade social brasileira articulada dinamicamente no interior de um sistema político, cultural, econômico e governamental hierárquico, porém interativo, dialógico e pretensamente democrático. A operacionalidade dos CRAS é dependente de uma lógica comunicativa que implica circulações constantes de informações com os níveis mais superiores do sistema de assistência social brasileiro conhecido como SUAS no que concerne à transformação de seus recursos humanos e infraestruturais no sentido da superação de problemas em termos de aprendizagem institucional sistêmica capaz de superar velhos paradigmas teórico-práticos. O SUAS deve consistir em um sistema, cujos elementos são humanos, técnicos e tecnológicos, capaz de aprender a superar obstáculos de modo a não repetir erros.

A democracia pressupõe comunicação constante entre agentes efetivos e ambientes institucionais em que estão inseridos. Indivíduos e grupos que compõe uma sociedade maior informam aos seus administradores se os programas de governo estão realmente melhorando suas vidas. Na medida em que a experiência aponta equívocos dos programas, esses devem ser reformulados, reprogramados ou mesmo desprogramados no sentido de se pensar novas visões teóricas e metodológicas sobre o estabelecimento de fins e meios sociais. Segundo Lemos e Lévy (2010, p. 51), a cibernética implica a ciência do governo, que investiga as formas de governo para promover modos menos contraditórios e mais efetivos, exigindo não apenas a correção dos meios, mas também dos fins. "Com efeito, não existe meio de realizar uma ação finalizada a não ser estabelecendo um [circuito] de comunicação entre um agente efetivo e o ambiente que ele modifica. $\mathrm{O}$ agente pode então comparar a informação sobre o efeito obtido com a informação sobre o efeito visado [...] na memória".

Aplicando essa lógica ao funcionamento dos CRAS no interior do SUAS, compreendemos que os primeiros são 
os agentes efetivos que tentam provocar algum efeito visado previamente pelos componentes programáticos mais abstratos ou menos empíricos do sistema (SUAS) como podem ser os casos CNAS responsáveis pelo acoIhimento, elaboração e discussão de propostas de PNAS, as quais se concretizam enquanto tais na forma de diretrizes, leis, planos e programas de governo, responsáveis por informar os princípios, meios e fins da Proteção Social Básica (PSB). É nesse sentido que Yasbek et al. (2012, p. 176) dizem que: "A capilaridade territorial do Cras deve aproximar as intervenções da política de assistência social à realidade de vida de indivíduos e famílias e suas necessidades sociais". Em termos cibernéticos, tal política implica documentos escritos com a função de servir como memória inicial do sistema, de modo que, durante a prática, os agentes efetivos não esqueçam e não se desviem de seus princípios, meios e fins. As ações práticas devem continuamente ser comparadas com os registros documentais memorizados (LEMOS e LÉVY, 2010, p. 52).

As principais memórias programáticas do SUAS são a Lei Orgânica da Assistência Social (LOAS) e a Norma Operacional Básica de Recursos Humanos (NOBRH), documento legislador conhecido como Resolução n. 269 do CNAS. A LOAS, promulgada em 1993, como continuidade do capítulo II, artigos 194 ao 204 da Constituição Federal de 1988, tem o papel de discutir a Assistência Social brasileira no interior do campo entendido como da Seguridade Social e da Proteção Social pública, implicando o direito, a universalização dos acessos, a responsabilidade do Estado em termos de Assistência Social como política pública enquanto ação teórico-metodológica que conscientemente intenciona tornar cidadãos todas as pessoas do país a partir da efetivação dos direitos, já que a Assistência Social não pode ser confundida com assistencialismo clientelista que concebe o exercício do direito como dom ou bondade natural de alguns poucos (COUTO et al., 2012b, p. 55). Para Couto et al. (2012b, p. 56), a LOAS inovou o desenho de funcionamento institucional para assistência social, que a nosso ver se trata de um desenho cibernético de governabilidade e governança democráticas.

A LOAS propõe "[...] o controle da sociedade na formulação, gestão e execução das políticas assistenciais e [...] [indica] caminhos alternativos para a instituição de outros parâmetros de negociação de interesses e direitos de seus usuários. Parâmetros que trazem a marca do debate ampliado e da deliberação [...] da cidadania e da democracia" (COUTO et al., 2012b, p. 56). O problema, como veremos, é que o novo proposto pela LOAS, mediante as propostas formuladas pela PNAS e NOB-Suas, "[...] surge na convivência e confrontação cotidiana com o 'velho', o tradicional; com longa trajetória patrimonialista de se compreender e de se fazer 'Assistência Social'"' (COUTO et al., 2012a, p. 232).

[...] a compreensão da política de assistência social, na perspectiva do Suas, é associada a necessidade de superação da cultura do assistencialismo/clientelismo e afirmação de explicitação do direito.

A NOBRH contém os princípios, meios e fins do SUAS inicialmente traçados na LOAS. Seu objetivo é governar as ações de seus agentes efetivos ou Recursos Humanos na implementação de técnicas e manipulação de tecnologias presentes no contexto empírico ou executivo do sistema, tal como são os CRAS enquanto capilares do SUAS responsáveis por detectar e agir conforme os parâmetros legais contidos na LOAS. Os CRAS são responsáveis por identificar as dificuldades apresentadas pelo ambiente que sofre as ações diretas e comunicar às esferas superiores ou programáticas do sistema a fim de que reformulem suas normas ou ofereçam alguma técnica ou tecnologia. Porém, democraticamente, algumas propostas de resolução não necessitam circular no sistema até os níveis superiores de programação, para só então enviar uma resposta. Vislumbra-se vias horizontais na solução de problemas, agilizando o processo e mantendo todo o sistema consciente.

Essa lógica teórico-metodológica cibernética entre os CRAS e o SUAS pode ser observada na literatura específica da área. Nas palavras de Yasbek et al. (2012, p. 173174), os CRAS consistem em porta de entrada do sistema federal. Nessa posição, os CRAS poderão "[...] organizar informações sobre o território e sua dinâmica e utilizá-las de forma estratégica, alimentar o planejamento das ações na própria unidade e subsidiar a elaboração do Plano Municipal de Assistência Social e o direcionamen- 
to (ou redirecionamento) da rede socioassistencial [...]". Além de sensores de demandas sociais, os CRAS são unidades de referência executoras de programas e planos contidos em leis e diretrizes governamentais, ao mesmo tempo em que, sendo porta de entrada, acolhe as contrarreferências do usuário do sistema socioassistencial em seu território de abrangência que, com outros, forma uma rede. Essa é uma das funções cibernéticas do CRAS, o

[...] fomento à organização da rede socioassistencial, cujo adequado funcionamento exige um fluxo e contrafluxo de usuários e de informações técnicas e gerenciais (ARTAMANN, 2003), de modo que os serviços e seus operadores construam entre si protocolos de ação [...] (YASBEK, 2012, p. 176).

Segundo Yasbek et al. (2012, p. 175), o trabalho social dos CRAS, cujo público alvo são as famílias habitantes de seu território, deve articular "[...] meios, condições, pressupostos éticos e conhecimentos teórico-metodológicos, com a finalidade de assegurar direitos e aquisições relacionadas à autonomia e ao fortalecimento da cidadania dos usuários, pelo desenvolvimento de suas capacidades e de condições objetivas de fazer frente às necessidades sociais de existência". A finalidade dos CRAS é realizar "[...] funções de proteção às famílias, defesa de direitos e vigilância das exclusões e violações sociais podendo [...] captar [enquanto sensor, receptor ou porta de entrada do sistema] necessidades de proteção social e agir [como braço executor dos programas elaborados pelos níveis superiores do sistema] preventivamente antecipando-se à ocorrência de riscos e aos agravos a vida" (YASBEK et al., 2012, p. 175).

Nesse contexto, o "[...] movimento de implementação dos Cras desencadeia debates e indagações de profissionais, gestores e pesquisadores sobre as formas de implementá-los, suas possibilidades e desafios" (YASBEK et al., 2012, p. 174) a serem enfrentados no eixo teórico-metodológico da intervenção, na medida em que a principal mudança é paradigmática consoante ao significado atribuído às unidades de ação do SUAS, que não podem perder de vista a necessidade de transformações no campo dos direitos sociais e, assim, da qualidade de vida cidadã, o que "[...] requer intervenções qualificadas do ponto de vista teórico, ético-político e técnico-operativo" (YASBEK et al., 2012, p. 174). Essas intervenções qualificadas exigem existências materiais e simbólicas de condições de governabilidade e governança que envolvem infraestrutura e recursos humanos condizentes com a LOAS e com a NOBRH.

Entretanto, a genealogia trabalhista é conduzida e induzida pelo sistema simbólico colonial no qual o Brasil está enraizado em prol de uma sociedade burguesa, branca e machista, em detrimento das diferenças que acolhe estruturalmente. O SUAS tem a difícil tarefa de vencer resistências históricas na busca pela construção de um sistema democrático de governo. A precarização das condições de trabalho não se trata de uma situação sincrônica, mas sim é uma continuidade das teorias e das metodologias coloniais instaladas no Brasil. A expansão dos contratos de terceirização da mão de obra, impedimentos na realização de concursos públicos, que não ocorrem há vinte e um anos, prevalência de vínculos temporários, crescimento de atribuições burocráticas, poucos profissionais qualificados em nível de graduação universitária específica, número elevado de agentes sociais de nível médio. $A$ isso se unem a ausência de espaços adequados com prevalência de espaços precários e improvisados, como antigas residências alugadas pelo poder público a fim de adaptarem o local para os serviços e recursos materiais (YASBEK et al., 2012, p. 177-178).

Isso "[...] supõe recorrer a abordagens interdisciplinares, que num diálogo amplo, façam convergir em uma unidade de propósitos, diferentes conhecimentos e saberes, práticas e iniciativas" (YASBEK et al., 2012, p. 198). Para tanto, alguns aspectos de ruptura devem ser traçados: a) reinterpretação crítica da família contemporânea; b) eleger como parâmetro teórico-metodológico transformações societárias, políticas, culturais e econômicas que vêm reconfigurando as famílias; c) ultrapassar visões moralizadoras e disciplinadoras que enquadram as famílias em normas e convenções rígidas em detrimento da diversidade; d) superação de relações de tutela; e) objetivar a promoção de autonomia e protagonismo social; f) promover acesso a direitos no sentido de desenvolver condições de convívio social; g) viabilizar as possibilidades objetivas e subjetivas de 
concretização de projetos pessoais e sociais; $h$ ) investimento em representações sociopolíticas para se apropriar de poder decisório por meio da auto-organização. Tudo isso, na tentativa de radicalizar a democratização dos modelos institucionais e de exercício da função pública (YASBEK et al., 2012, p. 195-197).

\section{Problemática descritiva da infraestrutura do cras de parintins-am e sua organização estrutural}

Seguindo uma das principais características da nova Assistência Social brasileira, o CRAS consiste em ser "[...] uma unidade estatal estrategicamente instalada no ambiente de moradia, de luta cotidiana e vivência das populações em situações de vulnerabilidade social [...]" (YASBEK et al., 2012, p. 178). "Conforme aponta Raichelis (2010), a implantação do Cras demarca a presença do Estado em território de maior vulnerabilidade social, o que deve resultar em novo protagonismo estatal, capacidade estratégica e coordenação política [...]" (apud YASBEK et al., 2012, p. 175). O CRAS onde realizamos o trabalho está localizado em um dos bairros periféricos mais populosos da cidade, com aproximadamente 13 mil habitantes, segundo o CENSO do IBGE realizado em 2010. Há queixas locais sobre evasão escolar, violência doméstica, alcoolismo, falta de saneamento básico, além de infraestrutura urbana precária relacionada a itens como asfalto, iluminação, áreas de lazer.

Sobre a infraestrutura, o locus em questão evidenciou restrições físicas relativas ao prédio onde ocorriam os trabalhos, comuns a outras situações distribuídas pelo país. Instalado em um terreno com medidas aproximadas de quinze metros de largura e trinta metros de comprimento, a edificação, de alvenaria e coberta com telhas de cimento, construída ao fundo da área, era formada por quatro salas uma ao lado da outra, cujas entradas eram cobertas por uma varanda comum. $\mathrm{O}$ ambiente apresentava iluminação artificial deficiente e sua climatização, realizada por aparelhos de ar-condicionado e ventiladores, além da possibilidade de pouca circulação de ar natural através de janelas e portas, proporcionava sensação térmica de calor elevado, gerando incômodos físicos e dificuldade de permanência em seu interior. Duas das sa- las eram utilizadas para a realização de atividades junto ao público atendido, uma abrigava a secretaria e outra, a cozinha para produção de almoços e merendas.

A varanda também era comumente utilizada para atividades pedagógicas. A parte externa contava com uma pequena cobertura com estrutura de madeira, semeIhante a um barracão e, à frente, havia uma construção inacabada semelhante a uma pequena quadra coberta. Entre o barracão e a quadra estavam espalhados muitos materiais de construção como areia, pedras, madeiras, ferros e ferramentas. Ao lado se contava com uma quadra improvisada de vôlei de areia. O lugar estava equipado com carteiras escolares, bancos, mesas, cadeiras, quadros de giz, aparelho de som, projetor de imagem, televisores e alguns precários materiais esportivos em número reduzido, como bolas, bambolês, rede de vôlei. Os três computadores eram destinados ao atendimento das demandas da administração, sendo às vezes cedidos para fins pedagógicos. Diante do portão de entrada, instalada na calçada, havia uma grande placa de identificação da instituição. Atualmente a referida unidade está instalada em outro endereço no mesmo bairro da cidade, apresentando meIhores condições de trabalho.

Yasbek et al. (2012, p. 177) evidenciam que restrições físicas como as descritas acima têm implicações metodológicas diretas de modo a instalar, conforme Castro (2008, p. 85, apud YASBEK et al., 2012, p. 177), "[...] o distanciamento entre as condições físicas do prédio 'e as orientações metodológicas que regiam a execução dos serviços"'. Espaços como esses remetem aos tempos em que a assistência social era guiada pelas noções de assistencialismo e filantropia, ao passo que a exigência por estruturas físicas condizentes com a utopia posta pela legislação aponta para a profissionalização do serviço social visando a favorecer "[...] adequado acolhimento ao usuário, do acesso a bens materiais e serviços [que] abrigam, em seu conjunto e em sua articulação, o reconhecimento dos direitos socioassistenciais assegurados pela Política de Assistência Social [...]" (YASBEK et al., 2012, p. 179). A infraestrutura descrita repete a encontrada por Yasbek et al. (2012, p. 178) em alguns CRAS de Minas Gerais, sendo "[...] observada a alternância de atividades em 
virtude [...] do espaço, além da insuficiência de [...] materiais para executá-las".

Como todos os municípios pesquisados por Yasbek e seus colaboradores, o CRAS de Parintins-AM possui computadores, alguns novos e outros com necessidade de manutenção. $\mathrm{O}$ acesso à internet consistia um problema constante devido à instabilidade da rede comum a todo o município. Tendo como carro chefe a fachada da instituição, geralmente apresentada por alguma placa, a identificação clara e atrativa para o público envolve preocupação teórico-metodológica em termos de abordagem dos usuários. A literatura reflete que as fachadas nem sempre apresentam uniformidade nos nomes, créditos oficiais e logos, dificultando a padronização da identidade visual do CRAS e, portanto, do SUAS como um todo. Não se limitando a placas, a identificação da instituição visando à construção de uma identidade com o público, a "[...] distribuição dos espaços internos nas edificações [...] pode limitar sua publicização, [...] quando se destinam espaços menos acessíveis e [...] precários para as atividades com o público, o que foi observado [...]" (YASBEK et al., 2012, p. 179).

Por esse viés, necessário se faz refletir sobre os modos como as pessoas envolvidas no CRAS organizam seus trabalhos no interior de seus limites físicos diretamente implicantes nos liames da democratização e humanização da assistência social. As movimentações e direções ocorrem mediante o "[...] envolvimento de técnicos, gestores, usuários e demais atores com as mudanças que estão em voga e as metas a serem alcançadas". Contudo, a diversidade nas instalações entre os CRAS revela

[...] que esta questão ganha maior importância em uma área que ainda não se criou um padrão de atendimento dos serviços, programas e benefícios de oferta em escala nacional, nem uma identidade visual dos Cras, que seja capaz de fixar junto à população o reconhecimento daqueles espaços como o lugar onde se realiza a proteção social básica [...] (YASBEK et al., 2012, p. 176-177).

Os espaços do CRAS parintinense organizavam-se conforme necessidades de uso divididas entre as atividades administrativas e as de formação técnica, tecnológica e humana. O conjunto de usuários é dividido em turmas de acordo com as atividades oferecidas e o interesse dos comunitários. A metodologia pedagógica pauta-se em palestras, orientações, cursos, minicursos, oficinas, aulas, reuniões, torneios, festivais, seminários etc. (YASBEK et al., 2012, p. 198-199) para interagir com os frequentadores. Tais atividades são organizadas por módulos temáticos, a depender das demandas de formação humana e profissional identificada pela administração e a equipe técnica do estabelecimento governamental, formada por assistentes sociais, pedagogos, psicólogos etc. Durante o ano em que desenvolvemos o trabalho de Al, mas também no decorrer de anos anteriores e dos seguintes, foi possível notar a repetição de uma sequência de temas, tais como: juventude e direitos humanos; juventude e cultura; juventude e meio ambiente; juventude e saúde; juventude, esporte e lazer; juventude e trabalho; mercado de trabalho (COSTA FERNANDO, 2013, p. 3).

A realização de atividades pode ser conduzida pelos próprios técnicos e monitores do CRAS, mas também por parceiros individuais e institucionais por meio de projetos e programas oferecidos à instituição pelas universidades (que foi o nosso caso), pela prefeitura, por Organizações Não Governamentais (ONGs), por entidades religiosas e outras entidades tanto de natureza pública como privada e filantrópica (COUTO et al., 2012a, p. 257). Yasbek et al. (2012, p. 183) observam isso como condução mista dos trabalhos para realização de oficinas e contratação complementar de trabalhadores, aquisição de materiais didáticos e espaços. Inseridos, nosso trabaIho de extensão não se restringiu à proposta $\mathrm{Al}$, já que o CRAS apresentou demandas no sentido de contribuirmos com o desenvolvimento de seus programas locais articulados a propostas e diretrizes regionais e nacionais. Assim, não foi possível concentrar nossas energias apenas no trabalho de $\mathrm{Al}$, de modo que uma parte do tempo foi divida com atividades diferentes ou contraditórias à nossa proposta.

Embora os esquemas pedagógicos realizados por meio de módulos temáticos e procedimentos como palestras, oficinas, cursos etc. cumpram importante papel no processo de formação técnica, tecnológica e cognitiva, esse tipo de prática pode ser caracterizada como tradicional e 
problemática às propostas democráticas devido ao seu caráter estrutural e unidirecional das informações e dos conhecimentos veiculados pelos formadores em detrimento do acervo metodológico, epistemológico e histórico latente no interior da realidade social atendida com capacidade de influenciar as esferas superiores do sistema, muitas vezes dominadas pela tecnocracia estatal e da meritocracia acadêmica. Os estudos sobre o SUAS e os CRAS apontam que o "[...] 'novo' proposto pela PNAS e NOB-Suas, surge da/na convivência e confrontação cotidiana com o [...] tradicional [...]" (YASBEK et al., 2012, p. 232). Porém, longe de qualquer visão maniqueísta, a contradição pode ser encontrada na prática de todos, inclusive dos progressistas, principalmente porque, apesar de conteúdos inovadores e críticos, a tradição didática da transmissão de saberes e valores ainda é predominante quando se fala em formação humana. Como no entendimento de Couto et al. (2012a, p. 252): "Importa enfatizar que a implementação da referida NOB ocorre em um contexto profundamente adverso ao conteúdo prevista pela mesma $[. . .]^{\prime \prime}$

Para Couto et al. (2012a, p. 253), “[...] o desafio está em intensificar o papel emancipatório que os profissionais têm e são responsáveis, para com a política e seus usuários". "Conseguir tornar este sistema mais um instrumento capaz de viabilizar politicamente a política, utilizando-se dos mecanismos como o Cras é apostar na ampliação dos serviços para a sociedade e na emancipação política dos sujeitos envolvidos nas reivindicações [...]". "Com a implementação do sistema e com avanços significativos na democracia do país, os cidadãos buscam efetivar suas garantias, que muitas vezes são impedidas pelos próprios executores das políticas". Inserida nesse complexo, a Al não se destina apenas aos conservadores, mas também aos progressistas, já que, desse ponto de vista, ninguém escapa da instituição histórica e cultural de um povo. Formados genealogicamente por uma história coIonialista, aqueles profissionais que conceituam a si próprios como radicalmente democráticos são passíveis, em um processo de Al psicanalítica, de identificar suas contradições mais sorrateiras. A metodologia de palestras, conferências e cursos estrutura uma relação humana em que necessariamente elegem e fixam um lugar do saber e ignorância.
Optamos por assimilar a metodologia local por refletirmos que a democracia não nasce do sectarismo maniqueísta de posições políticas e epistemológicas, mas sim da interação comunitária e fraterna no sentido da aprendizagem mútua, já que ninguém é ou pode se considerar absolutamente conservador ou revolucionário. Comportamos as contradições para o futuro da democracia, mas, também, suas vias de realização. "O Suas disponibiliza [...] uma série de instrumentos, documentos, legislações, experiências e mecanismos que revelam a complexidade do sistema e a necessidade da criação de espaços de capacitação" (COUTO et al., 2012a, p. 255). É necessário aproveitar os CRAS enquanto locais de acúmulos e rupturas entre teorias e práticas. Pautados em Freire (2011, p. 25), "[...] educar e educar-se, na prática da liberdade, é tarefa daqueles que sabem que pouco sabem [...] em diálogo com aqueles que, quase sempre, pensam que nada sabem, para que estes, transformando seu pensar que nada sabem em saber que pouco sabem, possam igualmente saber mais".

Nossa reflexão filosófica orienta que não compreendamos a extensão universitária como uma forma de substituir uma forma de conhecimento por outra. A extensão como substituição de saberes, em vez de diálogo entre eles, atual como prática cultural invasora, conquistadora e colonizadora, despertando no invadido uma reação de defesa ante o invasor, que sempre somos nós, os universitários, que ameaçam romper o equilíbrio interno local (FREIRE, 2011, p. 35). "Reconhecemos que a simples presença de objetos novos, de uma técnica, de uma forma diferente de proceder, em uma comunidade, provoca atitudes que podem ser tanto de desconfiança, de recusa, total ou parcial, como de aceitação" (FREIRE, 2011, p. 37). Não pudemos perder de vista que, ao refletirmos sobre a comunidade atendida, o próprio CRAS já é um invasor ou uma extensão do Estado e dos inúmeros interesses econômicos e políticos nele contidos, enquanto que nós, da universidade, embora também do Estado, aparecemos como invasores do CRAS e, consequentemente, da comunidade, base do trabalho. Somos versões ou subversões teórico-metodológicas de uma mesma estrutura.

"Assim, o trabalho técnico aponta que o principal desafio é a emancipação dos usuários e identifica as deman- 
das imediatas como empecilhos a isso, categorizando os usuários como incapazes" (COUTO et al., 2012a, p. 264). Podemos observar essas tendências no relato de um técnico de um CRAS do estado do Paraná

É [...] complicado trabalhar [...] reuniões, dar voz [aos usuários] porque [...] não sabem o que [...] querem, não tem esse tipo de abstração [teórico-metodológica; filosófico-política] é tudo [...] imediato e concreto, o que eu quero é comer hoje, amanhã e não sei, eu não sei do [...] futuro (TÉCNICO-PR, apud COUTO et al., 2012a, p. 264).

Mas, embora a queixa expressa acima coincida com a de Freire posta na sequência, o primeiro aponta para uma saída do imediatismo por meio da formação técnica enquanto que o segundo orienta para o equívoco da formação estritamente técnica, "[...] quando se tenta a capacitação de camponeses com uma visão ingênua do problema da técnica. Isto é, quando não se percebe que a técnica [...] é uma aplicação prática [...] condicionada histórico-socialmente [...]" (FREIRE, 2011, p. 40). Que toda técnica organiza ou estrutura uma dada sociedade localizada no tempo e no espaço, segundo Couto et al. (2012a, p. 262): "O debate sobre o mercado de trabalho é feito de forma [...] depreciativa em relação aos usuários, denotando a compreensão de que [...] não poderiam fazer nada além do que lhe é ensinado".

A reflexão deve se voltar à função dessa formação no interior da estrutura social envolvente: educandos e educadores. Não obstante, não se trata de desdenhar o conteúdo e a efetividade de uma formação técnica e tecnológica de um sujeito, mas sim de se atentar para a posição política e econômica que esse mesmo sujeito ocupa ao aderir a determinada formação profissional. A tendência encontrada, portanto, conformada com essa lógica tradicional de se interpretar e agir sobre as problemáticas sociais, diz respeito ao "[...] trabalho social para o fomento de prontidões para o mercado de trabalho [...] pela forma de oficinas de profissionalização voltadas a mulheres e adolescentes, antecipando o desenvolvimento desta prontidão, e contribuindo frequentemente para inserções precárias e subalternas no mercado de trabalho" (YASBEK et al., 2012, p. 199). Yasbek et al. (2012, p. 199) ainda sinalizam, com isso, que os CRAS assumem uma tarefa “[...] que não lhe cabe, reforçando improvisações e experiências laborativas precárias e de baixa qualidade e efetividade".

Deseja-se com isso conscientizar de que a aprendizagem de um ofício deveria ser compreendida como uma atividade cultural humanizante, em vez de contribuir com a lógica perversa do capitalismo na formação de mão de obra barata e ignorante quanto aos direitos, já que dificilmente tais formações poderão levar o sujeito a uma ascensão social, econômica e política, tampouco a uma desestruturação geral do sistema de classes visando a sua horizontalidade radical.

Além do problema da capacitação, identificam-se inúmeras dificuldades nas relações de trabalho que o próprio Estado, bem como os governos estaduais e municipais, não nos esquecendo de incluir as entidades parceiras, estabelecem com os profissionais. Contradizendo a própria NOB, os trabalhadores dos CRAS vêm estabelecendo suas relações trabalhistas com base "[...] na reestruturação produtiva em curso e do processo mundial de flexibilização das relações de trabalho" (COUTO et al., 2012a, p. 253). Segundo Couto et al. (2012a, p. 254): "[...] há ainda contratações irregulares de técnicos que acabam se perpetuando". As relações de trabalho dos CRAS, responsáveis por garantir os direitos dos usuários, são paradoxalmente problemáticas no mesmo sentido, devido a processos de terceirização, contratos temporários, além da utilização de estagiários remunerados (estudantes universitários).

Acerca do módulo temático "Juventude e Trabalho", a equipe do CRAS demandou de nós, no mês de outubro (2011), algumas palestras a serem ministradas por colegas professores da universidade no final de novembro e início de dezembro. A referida demanda foi certamente determinada pela transferência subjetiva e objetiva que se tem com as universidades enquanto referências de saber no que concerne à formação profissional e ao acesso ao mundo do trabalho e, por meio dele, uma possibilidade de ascensão econômica, política, cultural e social. O papel crítico e reflexivo das universidades é esquecido em favor de um pragmatismo, já que a intelectualidade 
é frequentemente vista como o contrário de qualquer tipo de solução prática e imediata dos problemas do capitalismo. Mas, interessados em atender a demanda justamente para nos mantermos na esteira de um processo de aprendizagem social e institucional, bem como manter e fortalecer os laços entre universidade e comunidade, mobilizamo-nos no sentido de convidar alguns professores da UFAM/ICSEZ/Parintins, conforme as linhas de interesse manifestadas pelo CRAS.

A partir de nosso convite, quatro professores compareceram às dependências do CRAS com datas previamente agendadas de acordo com programação de um conjunto maior de atividades relativas ao módulo. Os assuntos das palestras foram entregues a nós, de modo que a partir deles entramos em contato com professores cujos perfis certamente se adequavam à demanda. Os assuntos selecionados, seguidos da especialidade dos professores, foram os seguintes: a) Chefia e liderança (administração); b) Visões e estratégias para inserção no mercado de trabalho (sociologia); c) Empreendimento (administrador); d) Trabalho e conhecimento (pedagogo). Cada professor recebeu um certificado por colaborar.

Anterior e paralelamente às ações das palestras, nosso projeto de extensão abordou, com base em uma perspectiva da Al, o tema do mundo do trabalho e suas articulações com a constituição do desejo no jovem imerso nas demandas sociais. A nosso ver, adiantando um importante resultado de nossa prática junto ao CRAS, o desejo e a angústia vinculados ao mercado de trabaIho, além do conjunto de imaginários, símbolos e práticas que o circundam, não emergem da juventude como um interesse natural do sujeito em relação a tudo que se oferece socialmente. $O$ mercado de trabalho surge na vida do jovem moderno como uma demanda da sociedade, tanto por meio da família, quanto da escola, das igrejas e de outros setores sociais. $O$ jovem apresenta comportamentos mais relacionados com a angústia que propriamente com desejos claros e definidos. Contudo, o mercado de trabalho é construído como se fosse uma demanda do jovem desempregado. O problema, assim, é individualizado. A demanda do Outro social se confunde com sua demanda e seu desejo.
Buscando uma definição simples para Al é possível compreender que, para além de um procedimento metodológico fundamentado em bases teóricas restritas, estamos imersos em um campo teórico-metodológico plural cujas bases filosóficas e científicas podem ser encontradas na psicologia, na sociologia, na psicanálise, na antropologia, na pedagogia, na filosofia etc. Conforme leitura de Mansano (2003, p. 156) da obra de Baremblitt: "A Análise Institucional é composta por um corpo teórico bastante diversificado. [...] podemos considerá-la muito mais como um movimento institucionalista do que como uma teoria, visto que ela visa '[...] deflagrar nas comunidades [...] processos de autoanálise e processos de autogestão'". Esses processos estão intimamente ligados aos princípios críticos voltados à sociedade e ao Estado modernos sustentados nas práticas centralistas do poder e do controle sobre a produção das regras e leis em detrimento da descentralização e destituição democrática desse poder, a fim de fazê-lo circular em dinâmicas de negociações no campo do desejo, do inconsciente, do corpo, do ideal e da lei.

Por conseguinte, em diálogo com a administração do CRAS, combinamos encontros semanais com duas horas de duração, nos dias de sexta-feira pela tarde (das $15 \mathrm{~h}$ às $17 \mathrm{~h}$ ) contabilizando quinze encontros no total, o equivalente a trinta horas. As demais trinta horas foram distribuídas nas atividades de planejamento e avaliação do trabalho, bem como a construção do relatório, além de atividades paralelas realizadas além das sessenta horas que realizamos em parceria com o CRAS, tais como a organização de palestras e de uma rua de recreio dirigidas aos usuários, conforme expresso anteriormente. Em todos os nossos encontros, além dos jovens, sempre estev presente algum monitor ou técnico da própria instituição. Os encontros variavam entre dez a vinte e cinco participantes, considerando jovens do sexo masculino e do sexo feminino, não desconsiderando as classificações relativas à questão de gênero e sexualidade. Faixa etária: quatorze a dezessete anos.

A fim de atingir nossos objetivos, em especial a meta básica de os jovens se pronunciarem acerca de seus desejos e suas relações com as esferas da sociedade, utilizamos como recursos música, desenho, escrita, vídeos, fotogra- 
fias, teatro, jogos e conversas. Esses recursos, enquanto dispositivos da $\mathrm{Al}$, foram requisitados e sugeridos de acordo com o tema dos diálogos e a dinâmica das manifestações, já que muitas vezes o silêncio é imperioso nas metodologias que envolvem diálogo, por mais paradoxal que isso seja. $O$ primeiro encontro foi destinado à exposição do projeto aos jovens participantes. A exposição consistiu em transmitir informações sobre a origem do projeto e seus vínculos institucionais. Com efeito, apresentamo-nos como professores (dois) e estudantes (dois) da Universidade Federal do Amazonas (UFAM), unidade de Parintins, Instituto de Ciências Sociais, Educação e Zootecnia (ICSEZ). Detalhamos que a iniciativa estava vinculada aos cursos de Comunicação Social (coordenador) e de Educação Física (Vice coordenador e os dois estudantes).

Anunciamos ainda que dois dos monitores do PROJOVEM, contratados pela prefeitura, eram também estudantes do ICSEZ/UFAM, sendo um do curso de Comunicação Social e a outra do curso de Educação Física. Com base nessa contextualização, explicamos que o CRAS é uma instituição para a qual um das metas metodológicas é fazer parcerias com outras instituições, assim como com projetos e programas governamentais e não-governamentais a fim de que contribuam com o acesso da população atendida aos direitos sociais do cidadão. Doravante, explicitamos os procedimentos e a organização de nossos encontros, conforme descrito no parágrafo acima. Feito isso, passamos a conversar acerca da proposta da Al mediantes diálogos em grupo cujo tema central foi o desejo do sujeito e suas relações com a sociedade. Vale frisar que quando a palavra desejo foi pronunciada por nós, os jovens responderam com risos, gritos discretos e gestos de excitação, seguidos de silêncio.

Não sendo objetivo da presente descrição compor uma etnografia, prosseguiremos com um texto de caráter mais sintético destacando alguns pontos e acontecimentos mais relevantes do trabalho. Assim, refletimos que favorecemos uma perspectiva interpretativa da vivência, em vez de recair na crença positivista do realismo científico. Nossa perspectiva teórico-metodológica não crê na existência do fato em si mesmo, na medida em que todo fato ou acontecimento pode receber o estatuto de existente apenas se for apreendido por alguém ou alguma coisa. Não há fato ou acontecimento sem perspectiva, sem um corpo cujas capacidades de sensibilidade e movimento determinem radicalmente a estrutura do fenômeno. 0 fato, portanto, é sempre para alguém. Estruturalmente, muitos acontecimentos tendem a se repetir no interior de um dado grupo de acordo com uma certa temporalidade. A repetição é um fenômeno que condensa a temporalidade do sujeito individual e/ou coletivo específico.

Na clínica psicanalítica do sujeito, a repetição é uma espécie de morte no tempo, na medida em que não há diferença significativa capaz de o sujeito distinguir o hoje do amanhã. Em instituições, essa característica é marcante, pois elas prezam pelo controle dos atos por padrões de normalidade. Por isso, os dias de um presidiário em uma prisão parecem ser sempre os mesmos. Não sendo à toa a imagem do interno marcando os dias da semana na parede da sela por meio de riscos ser a metáfora dessa condição na busca por uma diferença, uma singularidade. Nas práticas de tortura, a solitária tem o objetivo de fazer o sujeito perder toda e qualquer referência de tempo e de espaço. Na solitária não há contraste de luz, de temperatura, de sons, de imagens. É a repetição do mesmo. Levando em consideração que a psicanálise trabalha e problematiza a alienação do sujeito ao Outro, esse mesmo é uma espécie de prisão subjetiva do ser em dado lugar e tempo psíquicos. Sem embargo, enquanto procedimento, o analista deve se atentar às repetições enquanto aprisionamentos, mas, consequentemente, às diferenças e distinções que surgem no processo.

O segundo encontro foi emblemático ao que se propõe a Al. A agitação do grupo era patente nas expressões corporais realizadas por meio de conversas, circulação no interior da sala, risos etc. Pouca atenção direta e declarada foi investida na figura dos analistas. Em meio ao que parecia uma confusão de movimentos, um participante perguntou: "por que estamos aqui?". Respondemos em meio a barulhos: "para falar do desejo". Em seguida, alguém, que parecia não estar com a atenção voltada para o trabalho proposto, se manifesta: "eu desejo não ficar aqui". Para tanto, devolvemos: "então, por que está aqui?". Rapidamente se levantou e caminhou até à porta dizendo: "vou sair!". Em um gesto automático, a monito- 
ra do CRAS, que já estava posicionada próxima à porta, levantou-se de modo a impedir a passagem do participante, dizendo-Ihe:"não!". Com um movimento irônico, o jovem deu meia volta e retornou ao seu lugar na posição sentada, dizendo: "ops!", enquanto alguns colegas continuavam conversando entre si e outros rindo da situação. Fazendo parte da cena, ou mesmo como corresponsáveis por ela, questionamos o jovem: "por que não saiu?". O mesmo nos disse: "você sabe!". Replicamos: "pode nos dizer?". Ele aponta para a monitora que ainda permanecia trancando a passagem. Aproveitamos a ocasião e com um tom de voz mais elevado lançamos: "o que fazer quando um desejo não pode ser realizado?".

O exemplo do jovem, a nosso ver, retratou evidentemente a repetição da estrutura social mais ampla. A expressa maioria não desejava estar ali, naquele ambiente social criado por nós. Não era a sala o problema, mas nossa presença responsável por uma simples demanda: que eles utilizassem aquele espaço físico e temporal para falar do desejo. Interessante refletir que, mesmo se negando a falarem para nós, na posição do Outro, acabaram, inevitavelmente, comunicando seus desejos pelo corpo, pelas realizações corporais. A ocasião do jovem que desejou e buscou efetivar uma saída pela porta iniciou um processo explícito de negociação de seu desejo com o Outro da instituição, representado pela monitora na função de interdição do desejo em favor da demanda do Outro enquanto lei. Nós, ao não insistirmos na demanda de sua presença ou ausência, abrimos um espaço ou lacuna no social para o desejo emergir ao nível do comportamento corporal, da descarga muscular significativa. Foi nesse momento em que o trabalho foi introduzido e aderido, enquanto negócio, no sentido da negação do ócio individual para o enfrentamento do outro e do Outro.

Concordamos com Yasbek et al. $(2012$, p. 184) quando observam: "[...] um conhecimento construído na prática dos profissionais acerca das necessidades e demandas sociais, embora raramente tenham sido detectados estudos para reconhecer, sistematizar e produzir indicadores [...]" das demandas. Contudo, torna-se importante frisar que não há reflexões sobre as demandas do SUAS para com seus usuários. Sobre isso, nossa hipótese é a de que tal sistema tem como papel certo controle social dos corpos e seus comportamentos na sociedade (YASBEK et al., 2012, p. 199). É necessário assumir que o Estado e a sociedade hegemônicos desejam que as comunidades e seus indivíduos assimilem uma dada lógica social, uma estrutura. $\mathrm{O}$ ambiente empírico ganha sua importância porque revela na micropolítica o inconsciente velado no discurso macropolítico. Até mesmo o analista vivencia a emergência do Outro inconsciente em sua prática. Não podemos negar que quando o jovem ameaça sair identificamos em nós um impulso em segurá-lo, mas que pela ética teórico-metodológica foi inibido, desviado, sublimado, transformado.

Nota-se que essa inibição realizada pelo analista significa que ele consegue barrar, com base em um terceiro, a psicanálise, o Outro da cultura autoritária que habita nele articulado à sua pulsão. Mais do que isso, ter sido capaz de inibir seu impulso uma vez não quer dizer que todas as vezes terá esse poder. É possível que em algum momento deixe o Outro operar seus comportamentos sem que haja tempo para perceber pela via de uma autocrítica ou autogestão. No encontro seguinte, contando com algumas variações como ausência de alguns e a presença de outros ausentes anteriormente, em um clima coletivo mais silencioso e tranquilo, retomamos a questão surgida na situação passada: o que fazer quando o desejo é inibido? Uma participante diz que o problema é que há sempre um outro que impede, que não deixa o desejo fluir. Questionamos: "o que se deve fazer com esse outro que impede a realização de um desejo?". Tivemos como resposta o silêncio permanente e inabalável. Incomodados com a circunstância, sugerimos um jogo teatral.

Cada um, anônimo, escreveu em uma tira de papel o que desejaria que o outro (o colega) realizasse com o corpo no campo dos gestos. Inserimos os papeis em uma urna. Feito isso, propomos uma dança das cadeiras, de modo que todas as vezes que alguém sobrasse, a prenda seria retirar um papel da urna e reproduzir o gesto que estava escrito. Outro detalhe importante foi que a cada rodada não foram retiradas as cadeiras, sempre permanecendo com o mesmo número, de modo a permitir a participação de todos, sempre, rompendo com a regra tradicional de ao final se ter um vencedor. A atividade discorreu de modo fluido com a participação lúdica de todos; nin- 
guém hesitou em participar do jogo, embora no momento de execução do gesto, determinado por outro, certa timidez se apresentasse, mas sempre vencida pela descontração e por saber que todos estavam na mesma situação. Vale dizer que participamos do jogo, enquanto analistas, submetidos às mesmas regras.

Após termos repetido algumas vezes o jogo teatral, ao passo que foi se tornando monótono, sugerimos retomarmos uma roda de conversa para falarmos de nossos sentimentos no cumprimento da tarefa, isto é, da regra combinada. Alguns confirmaram verbalmente a impressão que tivemos acerca da timidez, em especial aquela proveniente da situação de perante todos executar um gesto. Outros comentaram sobre o medo da incerteza sobre qual seria o gesto que deveria apresentar de acordo com a escolha cega e aleatória da tira de papel no interior da urna. Perguntamos se alguém, no momento de realizar o movimento descrito, vacilou, pensou em não realizar. Muitos responderam que sentiram vontade de não realizar a tarefa. Uma participante especificou que diante dessa vontade lembrava da regra acordada e, então, executava o aceno, também refletindo que gostaria de ver os colegas realizando os gestos. Um jovem acrescentou que além de lembrar-se de cumprir a regra, refletiu sobre ter percebido que ninguém descreveu gestos agressivos ou que viesse expor alguém ao ridículo.

Imediatamente outros se manifestaram argumentando que se tivessem que realizar algum movimento ridículo não o fariam ou mesmo sairiam do jogo. Perguntamos se isso não seria quebrar a regra anteriormente combinada, já que ninguém especificou a proibição de se propor gestos supostamente ridículos. Um dos participantes respondeu: "tem coisas que eu não faço... às vezes combinamos coisas sem pensar, mas nem por isso fico quieto quando a vergonha for muito grande". Segundo nossa interpretação, novamente a relação com o Outro está posta diante dos limites corporais do outro, do sujeito, seu desejo, suas fobias. Nesse jogo teatral, o Outro pode ser considerado a estrutura do jogo segundo suas regras, assim como a imaginação dos participantes acerca do que poderia ocorrer, o que estava por vir, que tipo de demanda teriam de atender na medida ou para além da medida dos limites de seus corpos moralizados. Mais uma vez os jovens demonstraram não estarem totalmente alienados ao Outro, pois não deixaram de questionar sobre seus excessos. Entretanto, a única saída que encontraram foi a fuga, retirando-se da estrutura das relações de poder de um sobre o outro, todos submetidos ao Outro. Não indicaram a possibilidade de propor uma mudança de regra para manter o laço. Preferiram desfazer o vínculo, deixar o grupo, a tencionar alguma mudança. Essa parece sempre ser proibida para a estrutura. É sempre mais fácil a exclusão.

Diante disso, ponderamos: "não seria melhor sugerir a pausa do jogo para rediscutir as regras?" Como retorno, ouvimos de alguém: "dá muito trabalho!" De repente, outra voz: "tem gente que não vai aceitar a mudança". Na mesma linha, esclarece um dos jovens: "por exemplo, se eu pego um papel em que está escrito um gesto que eu não quero fazer... Isso depois dos outros que já tinham feito o gesto... Esses iriam se sentir injustiçados... por isso iriam querer que eu fizesse o movimento". Mais um pronunciamento: "é! E quando isso acontece, o jogo começa a desmanchar, enfraquece..." Doravante, buscamos argumentar o seguinte: "vemos que o problema é o limite de cada um. O limite de um que não se sente à vontade em expor o corpo para cumprir uma regra, provoca o limite de um outro que não suporta que o outro não cumpriu uma regra que ele se esforçou para cumprir ou mesmo gostou de cumprir". Um jovem reclama: "é, por isso é injusto mudar as regras no meio... o esforço de quem fez fica perdido. $O$ jogo acaba e só ele fica ridículo de ter feito... inútil!" Nota-se nesse discurso que a regra pode beirar a tirania ao se sobrepor ao sujeito de desejo.

Questionamos: "o que é mais importante, a regra ou o limite das pessoas?" Obtivemos silêncio e resmungo. Continuamos: "parece que quando alguém questiona, não há mais volta... pra ninguém. Sendo assim, o grupo já fica fragilizado. Alguns querem sair, outros, mudar a regra; outros, deixar como está. O problema não estaria em continuar jogando junto ou não? Ou seja, o que se quer nesses momentos? Cumprir com a regra? Mudar a regra? Continuar jogando? Ficar perto dos meus colegas?" Alguém bate à porta para informar que já estávamos próximos do horário de encerrar. Aproveitando o gancho do corte, dissemos: "bom final de semana! 
Semana que vem estamos de volta". Aos poucos todos foram saindo e se despedindo descontraidamente. Os grupos e as sociedades se formam em torno de conjuntos de regras. Essas regras abstratas formam um Outro como lugar do controle, do julgamento, da avaliação, da memória etc., que age de modo a não somente manter uma dada estrutura de relações imposta a um coletivo. Parece haver uma regra ou mesmo uma problemática que coloca em jogo todas as regras ou todas as quebras de regras: o dilema da separação.

A situação descrita acima apresenta uma série de movimentos em que os sujeitos se vêm tendo que avaliar se é melhor sair, ficar ou transformar o jogo, tendo como parâmetro o limite do outro. Não há, portanto, uma pragmática nessas relações. É sempre difícil decidir entre o Outro e o outro. Ou seja, o coletivo das pessoas deve se render ao Outro e submeter o outro às regras, mesmo que ele não se adeque, sofra em se adequar? Ou, para manter o outro incluído, acolhendo sua dor, questiona-se o Outro da cultura, da instituição e lhe propõe adequações de modo que os vínculos grupais sobrevivam. Em termos estruturais, o problema parece discorrer sobre alterar o modelo de pensamento em função de uma vivência de sofrimento sentida no corpo, ou submeter esse corpo aos modelos de conduta e sensibilidade imposta por um conjunto de regras abstratas, nem que para isso se tenha que intensificar o controle sobre aqueles que ameaçam não serem capazes de cumprir as regras? Está posto nessas reflexões o mal-estar na cultura trabalhado por Freud. A cultura é ambivalente, dá um lugar ao sujeito, mas às custas de seu sofrimento, já que o preço pago é abdicar do desejo.

Nos encontros seguintes prevaleceram os debates sobre o mercado de trabalho. Atribuímos isso a uma questão que paira sobre a vida dos jovens, na medida em que a mídia, a família, os amigos, a escola etc. mantêm essa problemática viva diariamente, mas, no caso CRAS, de ser um tema obrigatório. Ao se propor a tratar dos direitos humanos e cidadãos como sua principal diretriz, o tema do trabalho, geração de emprego e renda, é inevitável e imperativo. O SUAS, por meio do CRAS, vê-se obrigado a dar alguma resposta aos jovens, assim como demanda desses alguns comportamentos que corres- pondam às mudanças esperadas pela instituição, sociedade e Estado, já que todos esses investem na resolução desse problema. Com efeito, estruturalmente a problemática do desejo e da sociedade se mantém na relação que o sujeito estabelece com o Outro, ou seja, com o sistema de regras, valores, ações, formas etc. que regem a comunidade da qual fazem parte. Essa relação não basta se for apenas objetiva, sua efetividade no sentido de sua capacidade em orientar, governar e determinar certos comportamentos depende de que o sujeito vivencie a objetividade na sua subjetividade.

Isso quer dizer que a negociação do sujeito em relação seu desejo e as interdições deve ocorrer internamente, representado no conflito de seus pensamentos. Apenas desse modo o Outro exerce poder sobre o sujeito ao nível de seus pensamentos, sentimentos e ações corporais. Observaremos a seguir como essa relação se manifestou, nos jovens do CRAS, tendo como referência o mercado de trabalho e o dilema das profissões. Podemos adiantar uma conclusão próxima de Freud acerca da escolha profissional, conforme Alberti (2004, p. 40): "Podemos concluir com Freud que a escolha profissional não dá margem para inúmeras possibilidades, ao contrário, implica um ponto de basta que intervenha na pluralidade infinda das possibilidades [...]". A pluralidade de possibilidades pode estar vinculada à pluralidade de demandas do Outro, por exemplo, as infinitas alternativas do mercado de trabalho. "Teoricamente falando, se todo sujeito é alienado ao Outro [...] a escolha se faz na vertente inversa, a da separação do Outro, sempre cortando e fazendo recortes nos desígnios e ditames em função do fato de que quando há escolha já nem tudo é possível" (ALBERTI, 2004, 42). Esse "nem tudo é possível" significa que nem tudo que o Outro exige é possível.

Entre uma coisa e outra, o jovem poderá avaliar, identificar, selecionar o que para ele é possível em dado momento segundo condições psíquicas, corporais e materiais dadas. Para Alberti (2004, p. 39): "Há de se supor que, no momento da escolha diante das inúmeras possibilidades, o sujeito possa delimitar uma, e aí, nesse momento, se o adolescente puder aí se engajar, investir, escolherá seguir esta ou aquela profissão". Quando o jovem permanece indeciso diante das possibilidades é porque não 
notou que o Outro cheio dos poderes tem suas falhas. Caso contrário, "[...] o adolescente se dá em sacrifício para tapar a falha do Outro". Como? Tentando ilusoriamente manter em seu campo virtual de ações um leque imenso de possibilidades, impossível de ser vivido em sua totalidade tanto psiquicamente quanto corporalmente. Ver a falta no Outro subjetivado é ver a falta, os limites, em si mesmo. $\mathrm{O}$ adolescente poderá escolher mais uma profissão caso ele observe os problemas e as falhas do próprio mercado de trabalho, que geralmente, enquanto Outro, oferece-se como perfeito ao mesmo tempo em que coloca o jovem como imperfeito e incompleto.

Revelou-se a relação do jovem com o mercado de trabalho no plano da demanda do Outro e de uma dúvida sobre seguir o desejo ou seguir um conjunto de regras arbitrárias e insustentáveis na prática. Além disso, um fortalecimento da demanda por parte das instituições de formação do jovem. Metaforicamente, tal como as igrejas fomentam o temor aos seus deuses, como forma de determinar comportamentos, as instituições modernas vinculadas ao Estado e à economia de mercado alimentam um temor do mercado de trabalho, de modo que aqueles que não se adequarem serão punidos com a exclusão ou com as funções menos valorizadas e gratificadas. De um ponto de vista crítico, o mercado de trabaIho deve ser visto como estruturalmente feito para falhar, para não abarcar todas as possibilidades, todas as mãos de obra oferecidas. Nos encontros que se seguiram, pudemos anotar alguns pronunciamentos por parte dos jovens sobre a questão do desejo dos participantes.

Dentre tantas possibilidades genéricas como ser: feliz, amigo, pessoa boa, trabalhador, estudioso, educado, bom filho, famoso, bom marido, bom pai, boa mãe, rico etc., destacaram-se mais os desejos por profissões, tais como: médico, advogado, professor, engenheiro, desenhista, artista plástico, astrônomo, enfermeiro, atleta, matemático, secretario, gari, jornalista, vendedor, físico, filósofo etc. Poucos disseram nada quererem. Desejos como ter carro, casa, motocicleta, computador, família, namorado, amigos etc. também foram frequentes. Concernente às profissões nos deparamos com um número maior de desejos voltados para a medicina, o direito e o atleta (futebol). Contudo, outra característica marcante foi o fato desses não se limitarem a uma opção; geralmente apontando para três ou mais profissões; "ser médico, engenheiro ou jornalista"; "astrônomo, engenheiro, enfermeiro ou professor"; médico, secretário ou professor" etc. As combinações são muitas e variadas.

Posteriormente fizemos a seguinte pergunta: "o que os outros desejam de vocês?". O padrão de respostas em relação à pergunta anterior não foi diferente. Certamente tinham como resposta o argumento que vimos traçando. Que o desejo do sujeito se confunde com o desejo ou a demanda do Outro. Para Alberti (2004, p. 42): "[...] todo desejo é, por definição, desejo do Outro". $E$, na medida em que o adulto deseja que a criança pare de chorar, como sinônimo do sofrer, ele demanda, além disso, que a criança se amamente, durma, fale, caminhe e assim por diante. Depois essas demandas, subjetivadas na mente infantil, tornam-se o desejo do sujeito. Grosso modo, a criança se apropria do desejo do Outro, já que ela não possuía qualquer desejo genético. $O$ problema, na adolescência, é se o jovem terá condições e certezas suficientes para continuar desejando que lhe foi anteriormente demandado.

Leiamos o que diz um dos participantes: "Eu creio que os desejos começam pelos pais por eles desejarem o melhor para seus filhos e eu creio também não é só disso, mas também como aquelas pessoas que querem melhorar sua rua ou algum elemento em seu dinheiro e etc.". Interessa notar o reconhecimento desse sujeito acerca de por onde o desejo começa: do discurso dos pais, que na verdade é do discurso do Outro da cultura que compartilham. Nas seguintes palavras encontramos conflito semelhante, mas, agora, na forma negativa: "[...] querem que a gente seja uma coisa que não queremos ser, principalmente na família [...]". Os discursos foram claros e objetivos ao demonstrarem como o desejo do sujeito é constituído a partir de referenciais coletivos externos a ele, os quais podem ou não assumir, questionar. Em mais um pronunciamento, lemos o seguinte: "O meu desejo faz pensar o que eu quero de mim mesmo. Porque tem os meus desejos e os desejos dos meus pais. Mas, entre o meu desejo e o deles eu prefiro o desejo deles. Por que é mais importante para mim". Repete-se o conflito entre o desejo do sujeito e o desejo do outro, mas que esses pais representam o Outro 
que, ao demandar da criança e do jovem, vai tornando esses, representantes do Outro também.

Deparamo-nos com algumas demandas descritas: "O que as pessoas querem de mim? Que eu me forme em uma faculdade de Direito e também querem que eu faça um curso para ser piloto de avião, e que eu seja a melhor pessoa do mundo". Semelhante a esse enunciado, tantos outros foram produzidos, sendo que destacamos a dualidade das demandas referentes à profissão: Advogado e Piloto de Avião. Necessário refletir sobre as distâncias práticas e institucionais entre ambos os ofícios. Levanta-se o problema do que é, para o jovem, com tão poucos recursos subjetivos, ter de escolher duas demandas díspares e ainda sem conhecê-las teórica e metodologicamente. Paulatinamente, como veremos, fomos perguntando se eles conheciam o esforço necessário para se atender a essas demandas, principalmente quando são distintas. Em outros discursos, as demandas provêm de setores sociais diferentes. Vejamos:

\begin{abstract}
Meus pais querem que eu me forme em medicina veterinária. Meus professores querem que eu seja esforçada, tenha um futuro brilhante, seja obediente, criativa, comprometida... Meus colegas querem que eu seja uma menina bem educada mais do que já sou, que eu me dê bem na vida... Eu quero me tornar uma pessoa bem sucedida, tanto nos estudos como na família...
\end{abstract}

No sentido de uma economia psíquica, corporal e, portanto, do ego, aos poucos introduzimos uma reflexão sobre capacidades e limites de cada um em atender tantas demandas. Não há limites para o desejo e a demanda, mas existem impedimentos para se atender o querer dos outros que formam o panorama ou o semblante de um Outro anônimo. Basicamente, o pedido que se dirige ao sujeito tem suas relações com a mudança; a demanda é que abandone um estado atual no sentido de outro já idealizado e projetado virtualmente. Os pais desejam que o filho engatinhe, quando apenas consegue sentar. Querem que ele caminhe, quanto apenas engatinha. As demandas seguem, assim, uma espécie de desenvolvimento pautada em um projeto idealizado. Refletindo sobre o capitalismo e seu mercado de trabalho, não é diferente a insatisfação para com o estado presente em favor de um dever ser futuro.
Contudo, o capitalismo aparelha a ontologia das demandas para prolongá-las de outras formas, com outros conteúdos e habilidades. No dizer de um jovem do CRAS, apreendemos: "Eu acho que as pessoas querem que eu mude!". O futuro aparece muitas vezes nos pronunciamentos: "Os meus pais desejam que eu estude para ter um bom emprego no futuro". Outra fala apresenta: "Os meus pais querem que eu seja um bom homem no futuro [...]". Vemos como a demanda se manifesta mediante projeções de uma dada identidade que não está formada. O futuro é uma espécie de algo a mais do e no presente, pois esse não nos basta, oferece-nos sempre menos do que se espera no campo da demanda e do desejo. Uma das jovens é bem clara e sucinta quanto a isso: "O que as pessoas desejam de mim: esperam muito mais". Sobre isso, encontramos mais demandas: querem "O meIhor de mim... minha felicidade. Que eu consiga concluir meus sonhos e objetivos. Que eu deseje cada vez mais".

Ponderamos junto aos jovens sobre o que vinham fazendo para atender às demandas lançadas sobre ou para eles. Àqueles que desejavam ser médicos, ou pelos pais ou por si mesmos, perguntamos o que estão fazendo para realizar tal desejo. Obtivemos alguns segundos de silêncio. Na sequência, reformulamos a questão: "O que é necessário fazer para ser médico, advogado, astrônomo etc.?". Imediatamente a seguir ouvimos vozes em uníssono: "Estudar!" Depois, alguns isoladamente: "Ser estudioso!"Alguns complementaram:"Se esforçar, ter disciplina!" Para tanto, devolvemos: "E vocês estão estudando de modo esforçado e disciplinado?". Fizeram silêncio e reformulamos a questão: "O que é necessário estudar para ser médico e qual é a quantidade de estudo para isso? Alguém sabe ou imagina?". Alguns disseram não terem compreendido a pergunta. Fomos mais diretos na questão: "Quantas horas do dia vocês dedicam para o estudo pensando no vestibular?". Complementamos: "Quantas horas vocês imaginam que um estudante de medicina estuda após ter passado no vestibular?". Responderam aleatoriamente: uma hora, duas horas, quatro horas? Em vez de responder à pergunta, lançamos outro questionamento: "como vocês dividem as atividades durante o dia?".

Prosseguimos para maior clareza: "vamos considerar que um dia tem duração de vinte e quatro horas. Des- 
sas vinte quatro horas, os especialistas aconselham, mais ou menos, oito horas de sono. $\mathrm{O}$ que equivale dizer que permanecemos acordados durante dezesseis horas por dia. Sendo assim, o que vocês fazem durante esse tempo acordados?" Muitos disseram que frequentam a escola pela manhã ou pela tarde, alguns poucos estão matriculados no ensino noturno, contabilizando cinco horas. Por conseguinte, subtraindo esse valor de dezesseis, restam onze horas. Sendo assim, provocamos a reflexão: "fora da escola, o que vocês fazem durante o restante do dia?" As respostas variaram desde assistir televisão, conversar com os amigos, praticar esporte, dormir, atividades domésticas, frequentar o CRAS, fazer trabalhos escolares, acesso à internet etc. Ninguém citou a palavra estudo.

Buscando conduzir os jovens para um confronto material ou corporal entre o desejo e o objeto do desejo (a profissão) tendo como caminho ou acesso o trabalho, ou seja, o investimento de tempo e energia corporal para uma data tarefa, trouxemos um dado estatístico baseado no estudo de Mitrulis et al. (2006, p. 280), no qual um dos resultados aponta que os estudantes que obtiveram sucesso no vestibular mais concorrido do Brasil, da FUVEST, destinado ao ingresso na Universidade de São Paulo, estudaram, em média, seis horas por dia, adicionais (contraturno) ao período de presença na escola. Restando, portanto, cinco horas para a realização de outras atividades, incluindo o lazer. Considerando que muitos estudantes pré-vestibulares vinculam, de alguma forma, esse último ao temas de estudo mediante filmes, museus, livrarias, revistas, jornais, jogos, além de conversas com amigos que estão na mesma situação etc., refletimos que com essa estratégia poderíamos levar a problemática do desejo para o encontro com o real do corpo inserido em uma dinâmica de estrutura natural, como o tempo de duração de um dia, da necessidade fisiológica do sono, das necessidades afetivas de promover relações e laços sociais. A nosso ver, o encontro com esse real facilitaria ao jovem projetar a problemática da escolha a partir dos limites materiais externos ao seu desejo.

Em suma, a intenção foi promover uma abertura para o sujeito avaliar suas condições diante da demanda do Outro, isto é, para verificar se essa demanda não estaria implicando em um pedido a mais, uma mais valia de tra- balho sobre a vida, a qual se paga com o apagamento ou abdicação do desejo, quando deveria se abdicar do Outro. Quinet (2009, p. 31) alerta que para a “[...] psicanálise, a verdade é da ordem da materialidade [...], se articula não com a presença, mas com a sua ausência". Aplicando esse raciocínio para a problemática do investimento de tempo e energia em algo, percebemos a ausência de tempo para se destinar ao estudo. Porém, se para isso falta, certamente sobra para outras escolhas. Sem embargo, para ter tempo dedicado ao estudo, será necessário faltar em algum lugar. Para nós, é nesse sentido que Lacan aponta que a causa da psicanálise, ou, a causa de entrada em análise é, segundo Quinet (2009, p. 32), “[...] a verdade sobre a castração [...]". A castração envolve a castração do Outro; que significa que esse falta, na figura de seu representante, a mãe, o pai, o professor, a assistente social etc. que nem sempre estão presentes para o sujeito.

Na medida em que se aceita a falta do Outro pela falta da mãe real, o sujeito pode se permitir faltar em algum lugar, para então ou por causa disso desejar. Realizando uma leitura de um dos textos de Quinet (1991, p. 32), nossa meta não era adaptar os sujeitos à realidade. Apostamos no procedimento freudiano de começar a introduzir os jovens atendidos em "[...] um primeiro discernimento [...] de sua posição no real [...]". O cálculo do tempo de vida para o estudo indicava uma tarefa de resolver a problemática da escolha da profissão no campo da vida real, em vez de o campo do Outro imaginário castrador. Assim, não é o Outro, o mercado de trabalho, que nos castra, mas sim nosso próprio real, as condições materiais de realização do desejo. Entretanto, no imaginário a ser desconstruído, o sujeito teme o Outro. Ao desconstruir o Outro ou o imaginário que se tem do mercado de trabalho, pode-se implicar uma espécie de "retificação subjetiva", que para "[...] Freud consiste em perguntar 'qual a sua participação na desordem da qual você se queixa" (QUINET, 1991, p. 32-33). A participação do sujeito em sua queixa geralmente está relacionada à sua incapacidade de escolha.

Não conduzimos essa parte da Al em termos de convencer os jovens de que deveriam abdicar de suas atividades diárias para estudarem visando ao vestibular de modo a atenderem o desejo do Outro, que pode ser, também, 
desejo do sujeito. O trabalho se desenrolou no sentido de colocá-los em um ponto em que a escolha pareça ser inevitável para que o desejo opere. Assim, o desejo supera a economia de mercado para adentrar a uma economia psíquica e corporal do sujeito. Nesse sentido, perguntamos ao grupo se diante das necessidades reais de se abdicar de outras coisas para poder estudar visando a um vestibular o desejo ainda resiste ou se desloca para outra coisa. Sendo mais diretos, provocamos: "quem está disposto a abdicar de horas de amizade, de sono, de televisão, de namoro, de distração etc. para ter em troca uma profissão?" Continuamos: "será que vale a pena trocar tudo isso por uma profissão ou seria possível unir todas as coisas? Por exemplo, quem deixaria de ir a uma festa para estudar?". Diante desses questionamentos alguns clichês foram reproduzidos: "é por isso que quem estuda fica chato e antissocial!".

Na sequência, um contradiscurso: "Mas, tendo uma profissão eu posso ter outros amigos... Tanto na universidade, quanto no emprego...." Para tanto, responderam: "É verdade! Eu tenho amigos que estão na universidade...." O debate se desenrolou para um diálogo, ou seja, para pontos de vista diferentes, geração de dúvidas no sentido de questionar verdades sólidas e absolutas. As discordâncias sobre o tema apontam que uma escolha pode ser uma restrição, mas não um fechamento. Ao escolher se abdica de muitas possibilidades, alguns jovens suspeitaram de que esse fechamento pudesse significar uma nova abertura para possibilidades desconhecidas, mas, ao mesmo tempo, com características semelhantes.

\section{Considerações finais}

O capitalismo, isto é, a economia de mercado, desde o ponto de vista da Al, configura, como pudemos argumentar, uma economia do desejo e do corpo. O desejo é inserido em um jogo de liberação, retenção, troca, valorização, utilidade, dissimulação, perda, prejuízo etc. Os jovens são muito claros ao falarem do mercado de trabalho de modo articulado à negociação constante que devem fazer com seu desejo e com o desejo do Outro, tendo como elemento decisório o corpo. Sabem que todo ganho envolve perder em troca. Toda perda é trocada por algum ganho. E, nesse jogo, tudo é posto na balança: o peso das perdas, o peso dos ganhos. Por conseguinte, a noção de justiça: é justo deixar de seguir o desejo para se submeter à demanda do Outro em troca de um emprego vinculado a um salário que visa à sobrevivência ou prazer de ordem física e uma mortificação do ser? É isso que está em jogo sempre na escolha de uma profissão: escolher entre aquela que eu gosto e aquela que paga melhor. Muitos escolhem por atender a demanda do Outro a fim de ganhar forças econômicas que possivelmente garantam que no futuro possam realizar o desejo recalcado, postergado.

Há escolhas que negociam entre o desejo e o mais fácil: deseja ser tal profissional, mas prefere uma profissão mais fácil, mesmo que essa pague menos. As negociações são muitas e variadas. Os laços sociais também são colocados no jogo de perdas e ganhos. Um dos dilemas apresentados por um jovem foi: conseguir um emprego qualquer e sair da casa da família ou permanecer morando com os pais de modo que pudesse continuar estudando sem trabalhar e assim poder vislumbrar o ingresso em uma universidade. Sair da casa da família envolve um imaginário em torno da liberdade psíquica e corporal. Esse mesmo sujeito deu um exemplo de amigos dele que saíram da casa dos pais e alugaram uma casa dividindo o aluguel. Disse que durante o dia trabalhavam e à noite ficavam ouvindo música e bebendo cerveja. Afirmou, sobre isso, ser esse seu ideal de vida. Ou seja, com isso estaria satisfeito. Ao liberar sua fala, graças à metodologia da $\mathrm{Al}_{\text {, }}$ provocou espanto em outros sujeitos, seus colegas, que disseram desejar serem médicos, advogados e astrônomo; como se fosse algo de outro mundo desejar um emprego qualquer para à noite poder relaxar comprando algumas cervejas com o dinheiro que recebeu a partir de seu trabalho. Ora, o emprego qualquer, a cerveja, o aluguel, os amigos etc. são coisas desse mundo e estão mais próximas da maioria ao compararmos com uma formação em medicina ou astronomia.

Busquemos observar que ligado a esse mercado de trabalho está um mercado do desejo e do corpo. Tais mercados que interagem por negociações cujos pagamentos, como gasto e ganho de energia, são realizados pelo corpo. A todo o momento é o ser e o estar do corpo do sujeito que subjaz a todo conflito entre trabalho e dese- 
jo, entre mercado de trabalho e mercado do desejo. E foi justamente nesse ponto que nossa Al promoveu uma espécie de descoberta, que entre o mercado de trabalho e o mercado do desejo existe o esforço corporal, sendo que esse esforço é o processo que pode ou não levar o sujeito do desejo a atingir seu objeto lançado no mercado. $O$ objeto desejado no mercado de trabalho é a profissão. Entretanto, esse objeto só pode ser apropriado pelo sujeito pelo mecanismo do ser em vez do mecanismo do ter. Lembremos como um modo de ser estava em questão no pronunciamento do sujeito que desejava ter um emprego qualquer para poder à noite beber uma cerveja e conversar livremente com os amigos. Os modos de ser são um tipo de objeto que o sujeito só pode consumir desde que reproduzam um dado comportamento o qual o levará a uma dada sensação. Vejamos como as profissões foram se tornando objetos de consumo no capitalismo.

Porém, as dificuldades imensamente maiores em se consumir uma profissão em comparação a um sorvete é o fato de o sujeito ter de sustentar certo padrão de comportamento corporal que exige esforços físicos e psíquicos que nem todos estão dispostos a pagar, mesmo que os ganhos posteriores sejam compensatórios. Não obstante, pudemos perceber que entre o objeto (a profissão) e o sujeito (desejo) subjaz algo inconsciente. Uma dimensão que a consciência não pensa, não leva em conta no cálculo dos esforços necessários para a realização do desejo. Como perguntou um jovem sobre o processo de escolher uma profissão: "quer dizer que tem que colocar tudo na ponta do lápis?". Momento em que respondemos: "inclusive a preguiça corporal". A preguiça faz alusão à falta de energia ou mesmo de desejo quando no meio do processo do trabalho se pensa em desistir. Mas esse desistir nada mais é do que recalcular os esforços. $O$ jovem, assim, na vivência corporal do ideal traçado tem a possibilidade de realmente sentir o valor corporal a ser pago pelo desejo, de modo que passa a refletir sobre a possibilidade de buscar objetos de desejos mais econômicos ou, em alguns casos, em objetos ainda mais caros em termos de energia corporal e laço social.

Foi enriquecedor descobrirmos junto aos jovens do CRAS que no capitalismo as profissões ou ofícios são oferecidos da mesma forma que outros produtos mais vinculados à dimensão do ter que a do ser. A descoberta envolveu compreender que o capitalismo se esforça para manter fora da consciência o esforço corporal necessário para o advento de um produto, seja um modo de ser ou algo a ter. Por analogia, identificamos que do mesmo modo que um jovem desconhece os esforços corporais necessários para alguém ser um professor ou um astrônomo; ele desconhece os esforços corporais envolvidos na produção do arroz e do feijão que ele consome à mesa em sua casa. Na economia de mercado passamos ter maior contato direto e acabado com os produtos em detrimento do contato com os processos, com os esforços, os corpos e os sujeitos desse processo. Assim, o chamado mercado de trabalho passa a ser traduzido em mercado das profissões. A partir desse momento, pudemos ensaiar algumas reflexões sobre as maneiras de se divulgar uma profissão por parte das instituições de ensino técnico e superior. Isso quer dizer que a vivência empírica, particular, levou-nos a refletir sobre a estrutura enquanto relação solidária entre seus problemas internos.

Por exemplo, certa universidade do país divulgou em sua página na internet o seguinte enunciado sobre seu vestibular: "Mais uma chance de começar do topo". Nesse caso, o vestibular é comercializado como sendo uma chance de começo. Mas trata-se de um começo que se inicia já desde uma referência de término, de conclusão: o topo. Metaforicamente, é como vender a ideia de que um alpinista começa a escalar sua montanha já desde o cimo. E, estando já no topo, para onde mais se pode caminhar? Ora, ou retorna para a base ou permanece confortável no topo. Necessário visualizar que tal enunciado é a chamada para um tipo de laço social entre sujeito e instituição. Tal laço ignora os esforços para que o mesmo seja mantido. As instituições vêm demandando vínculos com a sociedade a partir de um imaginário de facilidades, de ganhos sem esforços, das escolhas sem os dilemas das perdas.

Nesse contexto, a AI no CRAS pode contribuir para a construção de elos discursivos e cognitivos, no que pese a certo poder da lógica de projetar virtualmente o sujeito no campo dos esforços reais de seu corpo, entre os sujeitos e seus objetos de desejo. Tais ligações são possíveis somente mediante o envolvimento do corpo 
nesse processo. A profissão, na medida em que sua realização ou objetivação apenas pode ser constatada por meio de um comportamento adotado pelo sujeito, diz respeito à dimensão do ser que só pode ser constatada na dimensão do sentir e do pensar. Na visão de Sissa (1999, p. 127): "O ser humano é movido pelo prazer, critério primeiro na orientação dos desejos e dos projetos". Segundo a autora, Freud define prazer como sensação e como estado, isto é, como sentir e ser, respectivamente. "Como tal, em seu acabamento ideal, o prazer corresponde à realização de um desejo. [...] É entretanto sentido como [...] volta a um estado de repouso: Nirvana" (SISSA, 1999, p. 127). Observemos, por essa lente, como há uma esperança de repouso ao se imaginar atingindo um estado de profissionalização.

Recordamos, em outro contexto, trabalhando com professores indígenas, que muitos escolheram a docência porque seus pais diziam que ganhariam a vida sentados, em oposição ao esforço do roçado. Imagina-se que antes da profissão há a angústia com o mercado de trabalho, pois o sujeito se vê imerso em uma vida de não realizações e sofrimentos. Entretanto, a profissão é um novo começo de uma vida de trabalho, pois com a profissão se passa a saber um pouco para saber mais. No trabaIho não é o prazer que rege o corpo, mas algo além do princípio do prazer. Pois o que poderia alimentar um corpo que, ainda cansado, trabalha sem cessar de modo a ainda sentir algum prazer em meio aos desprazeres dos desconfortos musculares? Esse mais além é o gozo, que para Lacan (apud NASIO, 1993, p. 145), só se apreende pelo que é corpo. Contudo, essa poética da construção do saber na profissão foi instrumentalizada pelo capitalismo. A profissão não é o nirvana, mas, possivelmente, sinônimo de mais angústia diante do Outro.

Entregar-se à lógica do mercado de trabalho é se entre gar à atitude perversa do gozo do Outro em detrimento de qualquer tipo de singularização, individual ou comunitária, na alteridade. A Al poderia ter discorrido centralmente por muitos outros caminhos como a sexualidade, o casamento, a família, a amizade, a traição, a violência, a morte etc. Porém, por uma correlação de forças contemporâneas, proveniente de todos os lados, mas principalmente do próprio CRAS, já que seu estatuto assim orienta, todas as vertentes da vida foram orientadas pelo eixo central do trabalho, mais especificamente do mercado de trabalho. Essa concentração também se deve ao pouco tempo que estivemos presentes na instituição. Temos consciência de que um processo de análise exige mais tempo do que aquele disponibilizado para um projeto de extensão que compete com outras demandas e propostas, de modo que possamos vivenciar todos esse temas ou vicissitudes como fios condutores da vida.

De todo modo, a Al não se sustenta na categoria da totalidade, da satisfação do público, das carências, das demandas. A base psicanalítica da Al tende a levar os sujeitos a se depararem com a insatisfação, com a parcialidade da vida, com a fragmentação do mundo segundo nossas escolhas. Baseados nisso, supomos que o registro da existência de tal prática provoca, mesmo na sua ausência, sua presença, mesmo que seja discreta. Em psicanálise, a discussão pode discorrer sobre a análise terminável e interminável. Isto é, existe conclusão possível para uma análise? Não se sabe. O que se sabe é que ela tem um início, mas, como a vida, não se sabe se tem um fim com a ausência. Pelo poder simbólico da mente humana, todo ausente se faz presente em sua ausência, quando os presentes sentem sua falta no simbólico.

\section{Notas}

Renato Izidoro da Silva Doutor e mestre em Educação pelo PPGE/ UFBA, professor adjunto do Departamento de Educação Física da Universidade Federal de Sergipe (UFS). Líder do grupo de pesquisa Corpo e Governabilidade: política, cultura e sociedade (CNPq). E-mail: izidoro. renato@gmail.com

Gerson André Albuquerque Ferreira Doutorando em Sociedade e Cultura na Amazônia, Universidade Federal do Amazonas (UFAM), mestre em Sociologia pela Universidade Federal da Paraíba (UFPB), professor assistente do curso de Comunicação Social da UFAM, Instituto de Ciências Sociais, Educação e Zootecnia (ICSEZ). E-mail: sociologicus.ferreira@gmail.com

Tiago Marinho Dias Graduando do curso de Educação Física: Licenciatura da Universidade Federal do Amazonas (UFAM), Instituto de Ciências Sociais, Educação e Zootecnia (ICSEZ). E-mail: simpison@hotmail. com

Francisco José Fernandes da Silva Graduando do curso de Educação Física: Licenciatura da Universidade Federal do Amazonas (UFAM), Instituto de Ciências Sociais, Educação e Zootecnia (ICSEZ). E-mail: fernando.mar2009@hotmail.com 


\section{Referências}

ALBERTI, S. O adolescente e o Outro. Rio de Janeiro: Jorge Zahar Ed., 2004. (Passo-a-passo; 37).

COSTA FERNANDO, A. Políticas sociais e assistência social: o Programa ProJovem do CRAS Paulo Corrêa e o uso das toadas na afirmação da identidade cabocla. In: Anais, VI Jornada Internacional de Políticas Públicas, Universidade Federal do Maranhão, entre 20 e 23 de agosto de 2013; p. 1-10.

COUTO, B. R. et all. A implantação e implementação do Suas no Paraná e no Rio Grande do Sul: um movimento em processo. 2012

FREIRE, P. Extensão ou comunicação? Tradução de Rosiska Darcy de Oliveira. 15ª ed. São Paulo: Paz e Terra, 2011.

LEMOS, A.; LÉVY, P. O futuro da internet: em direção a uma ciberdemocracia. São Paulo: Paulus, 2010. (Coleção comunicação).

LOPES, C. dos S. et all.. A formação continuada dos profissionais do CRAS no município de Parintins. In: Anais, VI Jornada Internacional de Políticas Públicas, Universidade Federal do Maranhão, entre 20 e 23 de agosto de 2013; p. 1-10.

MANSANO, S. R. V. Análise institucional: relato de experiência com jovens. In: Psicologia em Revista, Belo Horizonte, v. 10, n. 14, p. 155-160, dez., 2003.

MITRULIS, E. et al.. Pré-vestibulares alternativos: da igualdade à equidade. In: Cadernos de Pesquisa, vol. 38, n. 128, p. 269-298, maio./ago., 2006.

NASIO, J.-D. Cinco lições sobre a teoria de Jacques Lacan. Tradução de Vera Ribeiro. Rio de Janeiro: Jorge Zahar Ed., 1993. (Transmissão em psicanálise)

QUINET, A. A estranheza da psicanálise: a Escola de Lacan e seus analistas. Rio de Janeiro: Jorge Zahar Ed., 2009.

As 4 + 1 condições da análise. Rio de Janeiro: Jorge Zahar Ed., 1991.

SISSA, G. Prazer e o mal: filosofia da droga. Tradução de Marcos de Castro. Rio de Janeiro: Civilização Brasileira, 1999. (Sujeito e História)

YASBEK, M. C. et all.. O Sistema Único de Assistência Social em São Paulo e Minas Gerais: desafios e perspectivas de uma realidade em movimento. 2012.

Data de recebimento 05/07/2014

Data de aprovação 08/08/2014

Data de aprovação 29/08/2014 
